\title{
The Effect of Size, Leverage to Earnings Response Coefficient (ERC) with Earnings Persistence as An Intervening Variable
}

\author{
Diamonalisa Sofianty \\ Lecturer in Accounting Department, Faculty of Economics and Business, Unisba, Indonesia
}

\begin{abstract}
The purpose of this study is to obtain empirical evidence about the effect of size and leverage on the earnings response coefficient (ERC) with earnings persistence as an intervening variable in manufacturing companies listed on the Indonesia Stock Exchange (IDX). This research uses path analysis. This research uses purposive sampling method in selecting samples from manufacturing companies listed on the Indonesia Stock Exchange (IDX) for the period 2010 to 2014. The results of the study indicate that size affects earnings persistence. Leverage does not affect earnings persistence. Size affects the earnings response coefficient (ERC). Leverage does not affect the earnings response coefficient (ERC). And the persistence of earnings does not affect the earnings response coefficient (ERC). The results also showed that the effect of Size and leverage on earnings response coefficient (ERC) through earnings persistence produced a very weak effect. The author's suggestion is that further research can extend the observation period so that better results are expected. In completing research the research time can be further extended so as to reduce errors in taking and processing data.
\end{abstract}

Keywords: size,persistence earnings, leverage, earnings response coefficient (ERC)

DOI: $10.7176 / \mathrm{RJFA} / 11-8-07$

Publication date: April $30^{\text {th }} 2020$

\section{Introduction}

Investment in the capital market is increasingly in demand by ordinary people, this can be seen by the increasing number of people investing their funds in companies that go public (Tiolemba and Ekawati, 2008). Financial statements prepared by the company's management are one source of accounting information that is useful for investors. The publication of financial statements through media mass can influence investment decisions for investors. This is due to the information contained in the financial statements considered new news about the state of the company in the capital market.

Accounting information that is needed in this case is profit information by investors, this information is used to invest in the capital market. Earnings information can describe how a company's performance and predict a risk in investment which is certainly very useful to support the right decision making in the selection of companies that will be the investment target.

Earnings information, in general, is a major concern in estimating management performance or accountability. Earnings information helps the owner or other parties assess the strength of the company's earnings in the future. This shows that profit is something that is most considered by investors to decide whether to invest or not, whether to sell the shares they have or not and whether to keep their investments. So important is this that has a lot of researchers who research the benefits of the information content of corporate profits, which begins by Ball and Brown (1968).

If in the past, research on accounting earnings was more focused on information content, the next development was more on how far the market response to accounting earnings information is better-known research Earnings Response Coefficient (ERC). Research in this area is focused on factors that influence the earnings response coefficient, which is the correlation between unexpected earnings and abnormal return on shares.

Earnings Response Coefficient or earnings response coefficient is defined as a measure of the abnormal level of stock returns in response to the component unexpected earnings (Scott, 2000). In general, the earnings response coefficient is measured by showing the coefficient slope in the regression of abnormal returns of stocks with earnings or unexpected earnings. This shows that the earnings response coefficient is a reaction to earnings announced by the company. The reaction given depends on the quality of the profits generated by the company. The reaction given depends on the quality of the profits generated by the company. Previous studies have shown that the earnings response coefficient is influenced by various factors including earnings persistence, capital structure, and company size.

Size (company size) is the size of the company that can be seen through the total assets owned by the company. Larger companies tend to have higher public demand for information compared to smaller companies. So that large companies will find it easier to innovate by utilizing the assets they have. These innovations will have a major effect on company profits. Size (company size) will have a positive effect on ERC. The larger the company, the greater the ERC of the company (Jogiyanto, 2009). The results of, Andayani (2007) and Ardila (2012) showed a positive influence on the firm size on ERC. This is contrary to Baginski (1999) which states size (company size) has a negative influence on ERC. While the research of, Syafrudin (2004), Martini (2007), Rosianawati (2012) 
found that there was no influence of company size on ERC.

The capital structure of the company in this study is proxied by the ratio leverage. A company with a level of leverage high means having a debt that is greater than capital. Thus if there is an increase in profits, the beneficiary is the lender, so the better the condition of the company's earnings, the more negative the shareholder response, because shareholders assume that the profit is only profitable for creditors. The results of research by Dhaliwal et al. (1991), Fitia (2003), Andayani (2007) showed that leverage affected ERC. While the results of research by Respiandi (2011), Ardila (2012) and Rosianawati (2012) show leverage does not affect ERC.

Earnings persistence is the effect of innovation on expected accounting earnings in the future (Kormedi and Lipe, 1987). The definition of earnings persistence by Penman (1992) is a revision of expected profit in the future(expected future earnings)is applied by innovation profit for the year(current earnings)so that the persistence of earnings views from the innovations in earnings associated with changes in stock prices. In some previous studies it was stated that earnings persistence was positively related to ERC (Andayani, 2007; Ardila, 2007; 2012). Research Respiandi (2011) gives the results of earnings persistence does not affect ERC.

This study aims to test the following: (1) direct effect of size on earnings response coefficient, (2) direct effect of size on earnings persistence, (3) direct effect of leverage on earnings response coefficient, (4) direct effect of leverage on earnings persistence, (5) the direct effect of persistence on earnings response coefficient, (6) indirect effect of size on earnings response coefficient through earnings persistence, (7) the indirect effect of leverage on earnings response coefficient through earnings persistence.

\section{Literature review and hypothesis development Effect of Size on Earnings Persistence}

Based on relevance theory, financial statements are a communication medium that can be used to evaluate past, present, and predict future events. Total assets as a proxy of company size are part of the financial statements. IFRS (2012) defines assets as resources controlled by an entity as a result of past events and from which future economic benefits are expected to be obtained by the entity.

The amount of total assets reflects the number of resources owned by a company in the company's main activities, where these activities tend to be used to make a profit (Yustiana, 2011). Large companies will also produce high-quality financial statements because large companies will have stability and operations that can be predicted better. So the estimation error caused is small (Dechow and Dichev, 2002). From the description above formulated the following hypotheses:

H1: Size a positive effect on earnings persistence.

\section{Effect of leverage on earnings persistence}

The level of debt will be greater if the more long-term debt is owned by the company. Shareholders benefit from financial solvency to the extent that the profits generated on borrowed money exceed the interest costs and also if there is an increase in the value of the stock market. Debt contains the consequence the company must pay interest and principal when due. If the profit condition cannot cover interest and the company cannot allocate funds to pay the principal, there will be a risk of failure. Therefore how much the desired level of debt, depends on the stability of the company.

Therefore, a high level of debt can provide a stronger incentive for managers to manage earnings in an acceptable procedure. The large level of corporate debt will cause the company to increase earnings persistence to maintain good performance in the eyes of investors and auditors. With this good performance, it is expected that creditors will continue to have trust in the company, remain easy to disburse funds, and the company will get ease in the payment process.

Fanani's research results (2010) show that the higher the level of debt, the higher the percentage. The results of the study Gu et al. (2002), Cohen (2003), and Pagalung (2006) show there is a positive influence between the level of debt on earnings persistence. From the description above, the hypothesis is formulated as follows: $\mathrm{H} 2$ : Leverage has a positive effect on earnings persistence

\section{Effect of Size on Earnings Response Coefficient (ERC)}

Companies that have large total assets indicate that the company has reached the stage of maturity. In this stage, the company's cash flow is positive and is considered to have good prospects in a relatively long period time, while also reflecting that the company is relatively more stable and more capable of generating profits compared to companies with small total assets (Indriani, 2005 in Zahroh and Utama, 2006).

Large companies have good performance and systems to control, manage, manage all assets owned by the company. This effective and efficient control, management and regulation of company assets has the potential to bring in profits. That is what causes investors to have more trust in large companies because large companies are considered able to continue to improve the performance of their companies by trying to improve the quality of their profits. Thus the greater the size of the company seen from the total assets, it will make investors increasingly 
respond positively to the announced earnings.

This is reinforced by the results of research Jang et al, (2007) which states that company size has a positive effect on earnings response coefficients. In line with research conducted by Zahroh and Utama (2006) which states that large companies will have a high earnings response coefficient. Easton and Zmijewski (1989) found variable size was not significant in explaining ERC. However, this variable can be used as a control variable for large and small companies.

Collins and Kothari (1989), found that firm size is negatively related to ERC. Negative relationship due to a large amount of information available throughout the year on the company, when the announcement of market earnings did not react. From the description above, the hypothesis is formulated as follows:

H3: Size has a positive effect on ERC

\section{The Effect of Leverage on Earnings Response Coefficient}

Companies that have a degree of leverage high tend to value the quality of earnings that are proxied with a low ERC because the profits reported by the company are profitable profits for creditors. Due to high debt, most of the profits will be distributed to creditors in the form of interest and principal payments, not to shareholders.

Dhaliwal, Lee, and Farger (1991) prove that leverage negatively affects the earnings response coefficient, namely ERC. A company with a high degree of leverage means having a debt that is greater than capital. Thus, if there is an increase in profits, the beneficiaries will be debtholders, so the better the company's earnings condition, the more negative the shareholder response will be because shareholders assume that the profit depends only on creditors. From the description above, the hypothesis is formulated as follows:

H4: Leverage harms Earnings Response Coefficient.

\section{Effect of Persistence on Earnings Response Coefficient}

persistence is a revision of expected earnings in the future which is applied by current year earnings so that earnings persistence is seen from current year earnings associated with changes in stock prices (Pennman in Palupi, 2006). Companies as financial statement makers expect accounting profit to approach economic profit or at least a good estimator. So that accounting profits remain beneficial for investors to determine economic profit according to its perception. The difference between accounting profit and economic profit will lead to unexpected earnings.

The definition of earnings persistence according to Scott (2003) is a revision of expected future earnings that are applied by current year's earnings innovation so that earnings persistence is seen from the earnings innovations of the year that are associated with changes in stock prices. The higher the persistence of earnings, the higher the $\mathrm{ERC}$, this is related to earnings strength.

Earnings persistence reflects the quality of the company's earnings and shows that the company can maintain profits over time. Kormendi and Lipe (1987) show that earnings persistence is positively related to ERC. Collins and Kothari (1989) also found a positive relationship between ERC estimation and persistence by using earnings changes as a proxy for unexpected earnings.

If the value of the company's surprise profit is low, the profit expected by the investor will be close to the actual return. In other words, the accounting profit is persistent because it can be used as an indicator to measure earnings for the next period so that it can be useful for investors to make investment decisions (Ambarwati, 2008). It can be concluded that the more persistent a profit is, the investor will respond well to the earnings information marked by rising company stock prices. So the higher the persistence of earnings the higher the value of earnings quality proxied by ERC. Palupi research (2006) concludes that earnings persistence is positively correlated with the earnings response coefficient. The statement was corroborated by research Mulyani et al. (2007) with results consistent with Ambarwati (2008). From the description above, the hypothesis is formulated as follows:

H5: Earnings persistence has a positive effect on the Earnings Response

Coefficient.

\section{Research methodology}

This study was designed to examine the direct effect of variable size and leverage on earnings response coefficient (ERC), as well as the indirect effect of size and leverage through earnings persistence on earnings response coefficient (ERC). The variable control included in this test is Growth to control variables earnings response coefficient (ERC).

\section{Sample selection}

The population in this study was 131 manufacturing companies listed on the IDX in 2010-2014. The sampling technique was purposive sampling technique through the following criteria, namely: (1) Manufacturing sector companies consumption goods industry listed on the Indonesia Stock Exchange from 2010-2014 (2) Manufacturing companies that were not delisted during the observation period (3) Audited financial statements of companies ending as of December 31. (4) Financial statements are expressed in rupiah because research is done in Indonesia. (5) The company did not experience a loss in the financial statements. 
From the results of the sample selection process based on established criteria, the number of research samples was obtained, namely, 64 manufacturing companies studied during the 5-year observation period, namely during 2010-2014 totaling 260. This research is research documents because the data examined are secondary, namely the financial statements of manufacturing companies listed on the IDX by downloading financial reports via www.idx.co.id and www.finance.yahoo.com.

\section{Variables and Measurement}

\section{Dependent variable (Dependent Variable)}

The dependent variable in this study is the Earnings Response Coefficient (ERC). Earnings Response Coefficient (ERC) is measured as follows:

$$
\mathrm{CAR}_{\mathrm{it}}=\sum_{+3}^{-3} \mathrm{AR}_{\mathrm{it}}
$$

Where:

- $\quad$ CARi.t $=$ Cumulative Abnormal Return (Accumulation of Returns Not Normal) securities $i$ at time t, accumulated from the abnormal return (AR) of the i-securities starting from the beginning of the event period ( $\mathrm{t} 3)$ to the $\mathrm{t}$-day

- $\quad$ ARhe = Abnormal return (return normal) for i-securities on the a-day, i.e., starting at $\mathrm{t} 3$ (day beginning of window period) until t-day

Where:

$$
\mathrm{AR}_{\mathrm{it}}=\mathrm{R}_{\mathrm{it}} \quad \mathrm{R}_{\mathrm{mt}}
$$

- $\quad \mathrm{AR}_{\mathrm{it}}=$ Abnormal Return (abnormal return) i securities in the t-event period.

$\mathrm{R}_{\mathrm{it}}=$ return actually happens for securities $\mathrm{i}$-th in the event period to $\mathrm{t}$

- $\mathrm{R}_{\mathrm{mt}} \quad=$ Return market index(market)in the event period to-t.

Where:

$$
R_{i . t}=\frac{P_{i . t}-P_{i . t-1}}{P_{i . t-1}}
$$

- $\mathrm{R}_{\mathrm{it}} \quad=$ Return of company i shares on day $\mathrm{t}$

- $\mathrm{P}_{\mathrm{it}} \quad=$ closing price of shares $\mathrm{i}$ on (days) $\mathrm{t}$

- $\quad \mathrm{P}_{\mathrm{it}-1} \quad=$ closing price of shares $\mathrm{i}$ on (days) before $\mathrm{t}$

Where:

$$
\mathrm{R}_{\mathrm{m} t \mathrm{t}}=\frac{\mathrm{IHSG}_{\mathrm{i} . \mathrm{t}}-\mathrm{IHSG}_{\mathrm{i} t \mathrm{t}-\mathrm{I}}}{\mathrm{IHSG}_{\mathrm{i} . \mathrm{t}-\mathrm{l}}}
$$

- $\quad \mathrm{R}_{\mathrm{mt}}=$ Return of market index in the period ( days) $\mathrm{t}$

- $\quad \mathrm{IHSG}_{\mathrm{it}}=$ Composite Stock Price Index in the period (days) $\mathrm{t}$

- $\quad \mathrm{JCI}_{\mathrm{it}-1}=$ Composite Stock Price Index in the period (days) before $\mathrm{t}$

Where:

$$
\mathrm{UE}_{\mathrm{it}}=\frac{\left(\mathrm{E}_{\mathrm{i} . \mathrm{t}}-\mathrm{E}_{\mathrm{it}-\mathrm{l}}\right)}{\mathrm{E}_{\mathrm{i} . \mathrm{t}-\mathrm{l}}}
$$

- $\quad \mathrm{EU}_{\mathrm{it}}=$ Unexpected earnings of the company $\mathrm{i}$ in the period (year) $\mathrm{t}$

- $\quad E_{i t}=$ Corporate accounting profit $i$ in the period (year) $t$

- $\quad \mathrm{E}_{\mathrm{it}-\mathrm{1}}=$ Accounting profit of company $\mathrm{i}$ in the previous (year) period $(\mathrm{t}-1)$

Where:

$$
\mathrm{CAR}_{\mathrm{it}}=\mathrm{a}+\mathrm{bue}_{\mathrm{it}}+\text { cit }
$$

- $\quad \mathrm{CAR}_{\mathrm{it}}=$ Cummulative Abnormal Return (accumulated return not normal) company i during theperiod observation \pm 3 days from the publication of thefinancial statements

- $\quad \mathrm{EU}_{\mathrm{it}}=$ unexpected earnings

- $\quad$ Eit $=$ component error in the model of company $\mathrm{i}$ in period $\mathrm{t}$

\section{Independent variable (Independent Variable)}

\section{Size}

Size in this study was obtained by natural log of total assets each company (Collins and Kothari, 1998 in Sri, $2007: 40$ ). In this study the size of the company is measured based on the amount of total assets owned by the company with the following measurements: 
Where:

$$
\mathrm{UP}_{\mathrm{it}}=\mathrm{LnTA}_{\mathrm{it}}
$$

- $\quad$ UPit $=$ company size $\mathrm{i}$ in the year period $\mathrm{t}$

- $\quad$ TAit $=$ Total company assets $\mathrm{i}$ in the year period $\mathrm{t}$

2. Leverage

In this study leverage is measured by calculating the debt ratio by comparing the total debt with the total assets of a particular company period (Dhaliwal et al, 1991).

\section{Debt Ratio $=\frac{\text { Total Liabilities }}{\text { Total Assets }}$}

Where:

- $\quad$ Debt Ratio $=$ Debt Ratio of company $\mathrm{i}$ in period $\mathrm{t}$

- $\quad T U=$ Total debt of company $i$ in period $t$

- $\quad \mathrm{TA}=$ Total assets of the company $\mathrm{i}$ in period $\mathrm{t}$

\section{Intervening Variables}

In this study, the variable used as an variable interveningis earnings persistence. In this study earnings persistence is measured by:

Where:

$$
\mathrm{X}_{\mathrm{it}}=\mathrm{a}+\mathrm{bX} \mathrm{X}_{\mathrm{it}-1}+\mathrm{E}_{\mathrm{t}}
$$

- $\mathrm{X}_{\mathrm{it}}=$ company profit $\mathrm{i}$ in period $\mathrm{t}$

- $\quad \mathrm{X}_{\mathrm{it}-1}=$ company profit $\mathrm{i}$ in period $\mathrm{t}-1$

\section{Control Variables}

In this study, variable used as a variable control is. Growth. Growth is measured by referring to Prasetiono \& Praise (2012) research, namely:

Data Analysis Method Data

The analysis uses path analysis because in this study there are intervening variables that describe the direct and indirect effects of a set of variables. In the current development of path analysis techniques can be done in framework modeling the equation structural (Structural Equation Model or SEM). Data processing using the AMOS (Analysis of Moment Structures) program version 24.0 trial version. The stages according to Hair et al (2006) and Ferdinand, (2005) are as follows: (a) Sample size plays an important role in estimating and interpreting SEM results. Chi-square figures are susceptible to the number of samples, so the recommended sample ranges from 100-200, (b) normality test, (c)Test Multicollinearity Singularity, (d) Test the suitability of the model.

\section{Research}

\section{Models Models for $\mathrm{H}_{1}$ and $\mathrm{H}_{2}$}

To test the effect of variable size and leverage on earnings persistence use the following equation model:

$$
\begin{array}{ll}
\mathrm{PERS} & =\beta_{1} \mathrm{SIZE}+\beta_{2} \mathrm{LEV}+\varepsilon_{1} \quad \text { (Sub-structural equation }
\end{array}
$$

\section{Models for $\mathrm{H}_{3}, \mathrm{H}_{4}$ and $\mathrm{H}_{5}$}

To test the effect of variable size and leverage to earnings response coefficient (ERC) using a model equation as follows:

$$
\mathrm{ERC}=\beta_{1} \mathrm{SIZE}+\beta_{2} \mathrm{LEV}+\beta_{3} \mathrm{PERS}+\beta_{4} \mathrm{GROWTH}+\varepsilon_{2} \quad \text { (Eq sub-structural 2) }
$$


In the case of this:

$\begin{array}{ll}\text { ERC }_{\text {it }} & =\text { Earnings Response Coefficient (ERC) of company } \mathrm{i} \text { in period } \mathrm{t} \\ \mathrm{SIZE}_{\mathrm{it}} & =\text { size of company } \mathrm{I} \text { in period } \mathrm{t} \\ \mathrm{LEV}_{\mathrm{it}} & =\text { leverage of company } \mathrm{i} \text { in period } \mathrm{t} \\ \mathrm{SIZE}_{\mathrm{it}} & =\text { growth of earnings of company } \mathrm{i} \text { in period } \mathrm{t} \\ \text { PRESS }_{\mathrm{it}} & =\text { company profit } \mathrm{i} \text { in period } \mathrm{t} \\ \text { GROWTH } & =\text { company growth i in period } \mathrm{t} \\ \varepsilon_{\mathrm{it}} & =\text { component of error company } i \text { in period } \mathrm{t}\end{array}$

\section{Results and Discussion}

\section{Descriptive Statistics}

Table 1 explains descriptively the variables in this study. Earnings response coefficient (ERC) has an average of 01148. This means that manufacturing companies in Indonesia have an average ERC of 0.1148 . With a positive ERC value, it means in making investment decisions in manufacturing companies investors use earnings information. The response coefficient highest-earning(maximum) is 0.5481 and the lowest (minimum) is -0.40 and the standard deviation is -0.6871 .

Table 1 Descriptive Statistics

\begin{tabular}{|l|c|c|c|c|c|}
\hline & Mean & Median & Maximum & Minimum & Std. Deviation \\
\hline LEVERAGE & 0.4112 & 0.3972 & 0.8004 & -0.0943 & 0.1734 \\
SIZE & 27.9422 & 27.7579 & 33.095 & 25.3084 & 1.5689 \\
ERC & 0.1148 & 0.0135 & 0.5481 & -0.6871 & 0.2022 \\
PERSISTENCY & 0.4035 & 0.4699 & 1.7101 & -1.0293 & 0.5731 \\
GROWTH & 0.1228 & 0.1259 & 0.4641 & -0.2069 & 0.1194 \\
\hline
\end{tabular}

Source: Data processing data

Variable size companies have an average 27,9422 from this it can be seen that the average size of manufacturing companies in Indonesia is included in large companies. The minimum value of the company size variable is 25.3084 the maximum value is 33.095 and the standard deviation or data distribution of the average is 1.5689

variables Leverage has an average of 0.4112 from this it can be seen that the debt level of manufacturing companies in Indonesia is included due to averaging around $41 \%$. The minimum value of the variable leverage company'sis -0.0943 The maximum value is 0.8004 and the standard deviation or distribution of data from the average is 0.1734

The earnings persistence variable has an average of 0.4035 . The minimum value of the company's earnings persistence variable is -1.0293 , the maximum value is 1.7101 and the standard deviation or distribution of data from the average is 0.5731

The variable growth has an average of 0.1228 . The minimum value of the variable growth company'sis 0.2069 , the maximum value is 0.4641 and the standard deviation or distribution of data from the average is 0.1194 .

\section{Hypothesis Testing Results Hypothesis}

Testing is done by comparing the p-value with a significant level (alpha) of 0.05 . If the p-value is less than alpha 0.05 then Ho is rejected, which means there is a significant effect between the two variables. If the p-value is greater or equal to alpha 0.05 then Ho is accepted, which means there is no significant effect between the two variables.

Table 2 Test Results of theHypothesis

\begin{tabular}{|c|c|c|c|c|c|c|}
\hline & \multicolumn{3}{|c|}{ Path } & $\begin{array}{c}\text { Std } \\
\text { Estimate }\end{array}$ & p-value & Conclusions \\
\hline $\mathrm{H}_{1}$ & SIZE & $\square$ & PERS & 0.058 & 0.029 & Positive, significant \\
\hline $\mathrm{H}_{2}$ & LEV & $\square$ & PERS & -0.350 & 0.145 & Negative, insignificant \\
\hline $\mathrm{H}_{3}$ & SIZE & $\square$ & ERC & 0.019 & 0.043 & Positive, significant \\
\hline $\mathrm{H}_{4}$ & LEV & $\square$ & ERC & 0.016 & 0.849 & Positive, insignificant \\
\hline $\mathrm{H}_{5}$ & PERS & $\square$ & ERC & 0.021 & 0.762 & Positive, not \\
\hline
\end{tabular}

significant $5 \%$

Hypothesis 1 test results are known to p-value $0.029<$ alpha 0.05 , then $\mathrm{H} 1$ is accepted. The regression coefficient of 0.058 indicates the effect between size on persistence is positive. That is, an increasingly large size will encourage companies to innovate using their assets. With this innovation, it will affect company profits.

The test results are known as hypothesis 2 p-value $0.145>$ alpha $0.05, \mathrm{H} 1$ is rejected. The regression 
coefficient of -0.350 indicates the effect of leverage on earnings persistence is negative, meaning that the higher the level of debt the higher the persistence of earnings will decrease but in this study the effect is not significant.

The test results are known as hypothesis 3 p-value $0.043<$ alpha 0.05 , then $\mathrm{H} 1$ is accepted. The regression coefficient of 0.019 indicates the effect between size on the earnings response coefficient (ERC) is positive. That is, size the larger will encourage companies to use assets to run businesses so it has the opportunity to make a profit.

The test results are known as hypothesis 4 p-value $0.849>$ alpha $0.05, \mathrm{H} 1$ is rejected. The regression coefficient of 0.016 shows the effect of leverage on the earnings response coefficient (ERC) is positive, meaning that the higher the level of debt, the higher the earnings response coefficient (ERC) and this is contrary to the theory that should be negative, and also the result is not a significant effect.

The test results are known as hypothesis 5 p-value $0.762>$ alpha $0.05, \mathrm{H} 1$ is rejected. The regression coefficient of 0.021 indicates the effect between earnings persistence the earnings response coefficient (ERC) is positive, meaning that the higher the persistence of earnings, the higher the ERC, this is related to earnings strength but these research results are not a significant effect.

Table 3 Test Results Indirect Effects

\begin{tabular}{|c|c|c|}
\hline Path Analysis & Std Estimate & Conclusion \\
\hline SIZE $\square$ PRESS $\square$ ERC & 0.010 & Indirect effect is very weak \\
\hline LEV $\square$ PRESS $\square$ ERC & -0.006 Indirect & effect is very weak \\
\hline
\end{tabular}

Source: Results of Data Processing

In testing the indirect effect involves intervening variables (mediating) as an intermediate variable. In this study, the indirect effect between size on earnings response coefficient (ERC) shows a coefficient indirect effect of -0.010 . Observed from the coefficient value, it can be concluded that the magnitude of the effect of size on the earnings response coefficient (ERC) through earnings persistence is very weak. Meanwhile the results of testing the coefficient direct effect between size and earnings response coefficient (ERC) of 0.149 is greater than the coefficient indirect effect. Based on the results of tests direct and, the indirect effect it is concluded that size has a significant effect on the earnings response coefficient (ERC).

Furthermore, leverage on the earnings response coefficient (ERC) shows a coefficient of the indirect effect of -0.006. Observed from the coefficient value, it can be concluded that the magnitude of the effect of leverage on the earnings response coefficient (ERC) through earnings persistence is very weak. Meanwhile, the results of testing the coefficient direct effect between leverage against the earnings response coefficient (ERC) of 0.014 is greater than the coefficient indirect effect. Based on the results of tests direct and, the indirect effect it is concluded that leverage has a significant effect on the earnings response coefficient (ERC).

Table 4 Testing Results Control Variables

\begin{tabular}{|c|c|c|c|c|c|}
\hline Path & & & Std Estimate & p-value & Conclusion \\
\hline GROWTH & $\square$ & ERC & 0.037 & 0.762 & $\begin{array}{c}\text { Positive, } \\
\text { insignificant }\end{array}$ \\
\hline
\end{tabular}

In the model proposed research, there is one control variable, namely Growth The test results are shown in the table above, it is known there is a significant positive effect growth to earnings response coefficient (ERC) where (p-value $0.762>0.05)$.

\section{Discussion of the}

\section{Effect of Size on Earnings Persistence}

Based on the results of the statistical analysis in this study it was found that the first hypothesis (H1) was accepted. From the results of data processing, it was concluded that the size (company size) has a significant effect on earnings persistence, which is the prob value. $0.029<0.05$.

Zahroh (2006) states that the larger a company will be responded positively by investors. This is because large companies are in the maturity stage. At this stage, the company's cash flow is positive and is considered to have good prospects in the long run. Also, large companies are relatively more stable and able to generate profits compared to small companies. Large companies have good performance and systems in controlling, managing and managing all of their assets.

The size of the company is one of the factors that determine the size of the company's assets. The larger a company, the greater the funds owned so that the company will maintain and will develop the company to earn profits every year. 
The results of this study are consistent with the 2011 Yustiana study in which the amount of total assets reflects the number of resources owned by a company in the company's main activities, where those activities tend to be used to make a profit.

\section{Effect of Leverage on Profit Persistence}

Based on the results of the statistical analysis in this study it was found that the third hypothesis (H2) was rejected. From the results of data processing concluded that leverage does not have a significant effect on earnings persistence with a sig value of $0.145>0.05$.

High levels of debt can provide a stronger incentive for managers to manage earnings in an acceptable procedure. The large level of corporate debt will cause the company to increase earnings persistence to maintain good performance in the eyes of investors and auditors. With this good performance, it is expected that creditors will continue to have trust in the company, remain easy to disburse funds, and the company will get ease in the payment process.

The results of this study are not consistent with the study of Gu et al. (2002), Cohen (2003), and Pagalung (2006) where their research shows that there is a positive influence on the level of debt with earnings persistence

\section{The effect of size on Earnings Response Coefficient}

Based on the results of the statistical analysis in this study it was found that the third hypothesis (H3) was accepted. From the results of data processing, it was concluded that size has a significant effect on the earnings response coefficient with a sig value of $0.043<0.05$.

Zahroh (2006) states that the larger a company will be responded positively by investors. This is because large companies are in the maturity stage. At this stage, the company's cash flow is positive and is considered to have good prospects in the long run. Besides large companies are relatively more stable and able to generate profits compared to small companies. Large companies have good performance and systems in controlling, managing and managing all of their assets.

Based on the results of the statistical analysis shows that company size has a significant influence on Earnings Response Coefficient (ERC), which means that company size is a reference by investors in making investment decisions. Therefore the size of the company is of concern to investors and responds more to the profits generated.

\section{Effect of Leverage on ERC}

Based on the results of the statistical analysis in this study it was found that the third hypothesis (H3) was accepted. From the results of data processing, it is concluded that size has a significant effect on earnings persistence with a sig value of $0.849>0.05$.

The results of the test indicate that the first variable (leverage) is a factor that gives a negative influence on the earnings response coefficient (ERC) but is not significant. The direction of this test is by the fourth hypothesis (H4), which is stated negatively. This study is not by the results of research from Dewi (2010), Murwaningsari (2008), Tiolemba and Ekawati (2008), and Mulyani et al (2007). A company with a high level of leverage means having a debt that is greater than capital.

High levels of debt can provide a stronger incentive for managers to manage earnings in an acceptable procedure. The large level of corporate debt will cause the company to increase earnings persistence to maintain good performance in the eyes of investors and auditors. With this good performance, it is expected that creditors will continue to have trust in the company, remain easy to disburse funds, and the company will get ease in the payment process.

The results of this study cannot show conformity with the theory which states that the higher the level of corporate leverage, the heavier the financial burden faced by the company, this means the higher the risk faced by the company. So, the higher the level of corporate risk means the higher the level of uncertainty of the company's survival, so the smaller the earnings response coefficient (ERC).

\section{Effect of Profit Persistence on Earnings Response Coefficient}

Based on the results of the statistical analysis in this study it was found that the third hypothesis (H3) was accepted. From the results of data processing, it was concluded that earnings persistence did not have a significant effect on the earnings response coefficient, with a sig value of $0.762>0.05$.

The fourth hypothesis (H5) of this study is earnings persistence influences ERC. From the statistical test results obtained a significant value of $t$ is 0.123 . This significant value of $t$ is greater than $=0.05$. It can be concluded that statistically, earnings persistence did not significantly influence ERC.

Earnings persistence is the effect of innovation on accounting earnings expected in the future that is associated with changes in stock prices. This means that with the innovation of accounting earnings is expected to be an increase in the company's stock price. An increase in stock prices will increase the value of ERC. But in reality, this does not affect the company's stock price. This may be caused by investors not too concerned with the 
existence of innovation. It may be that investors assess the profit innovation made by the company has a negative value for the company. The results of this study are in line with the results of research by Respiandi (2011).

\section{CONCLUSIONS, LIMITATIONS AND SUGGESTIONS}

The results showed that (1) Size had a significant effect on earnings persistence. (2) Leverage does not have a significant effect on earnings persistence. (3) Size has a significant effect on Earnings Response Coefficient (ERC). (4) Leverage does not have a significant effect on Earnings Response Coefficient (ERC. (5) Earnings response does not have a significant effect on Earnings Response Coefficient (ERC)

The results showed that the indirect effect of variable size and leverage on Earnings Response Coefficient (ERC) through earnings persistence variables was very weak.

The limitation in this study is that the observation year is only five years, so it is likely that the results of the study are not as expected. And also the time to complete the research that was devised too short (1 month) caused the possibility of an error in retrieving and processing data.

The author's suggestion is that further research can extend the observation period so that better results are expected. In completing research the research time can be further extended so as to reduce errors in taking and processing data. It is likely that the results obtained will be more in line with expectations.

\section{REFERENCES}

Andayani, Nur Fadjrih Asyik, Sri Mulyani. 2007. Faktor-faktor yang Mempengaruhi Earnings Response Coefficient pada Perusahaan yang Terdaftar di Bursa Efek Jakarta. Jurnal Akuntansi dan Keuangan. STIE Surabaya.

Anthony, Robert N., and Govindarajan, Vijay. 2004. Management Control System. Salemba Empat: jakarta

Ambarwati, Sri. (2008). Earnings Response Coefficient. Akuntabilitas (volume 7, no. 2).

Ardila, Isna. 2007. Analisis Faktor-faktor yang Mempengaruhi Earnings Response Coefficient (Studi Empiris pada Perusahaan yang Terdaftar di Jakarta Islamic Index). Thesis. Universitas Sumatera Utara.

Baginski, SP 1999. The Relationship Between Economics Characteristics and Alternative Annual Earnings Persistence Measures. The Accounting Review 74. January.

Ball, R. And P. Brown. 1968. An Empirical Evaluation of Accounting Income Numbers. Journal of Accounting Research 6. Autumn.

Cho, JY and K. Jung. (1991). Earnings Response Coefficient: A Synthesis of Theory and Empirical Evidence. Journal of Accounting Literature. 10: 85-116.

Collins, DW, and SP Kothari. 1989. An Analysis of Intertemporal and Cross-Sectional Determinant of Earnings Response Coefficient. The Journal of Accounting and Economics.

Chaney, PK dan DC Jeter, 1991, The Effect of Size on the Magnitude of Long Window Earnings Response Coefficients", Contemporary Accounting Research 8, No.2 : 540-560.

Dewi, Syanti. (2010). Pengaruh Ukuran Perusahaan, Tingkat Leverage, Komite Audit Dan Disclosure Terhadap Earnings Response Coefficient Pada Perusahaan Publik yang Terdaftar Di BEI. Jurnal Akuntansi (tahun XIV, no. 1).

Dhaliwal, DS, KJ Lee dan NL Fargher. 1991. The Association Between

Unexpected Earnings and Abnormal Security Returns in the Presence of Financial Leverage. Contemporary Accounting Research 8.

Dyer, JCIV. and AJ McHugh,1975." The Timeliness Of The Australia Annual Report”. Journal of Accounting Research. Autumn pp.204-220.

Easton, PD dan M. Zmijewski. 1989. Cross-sectional Variation in the Stock Market Response to Accounting Earnings Announcements. Journal of Accounting and Economics.

Fitria, Setiati dan Indra Wijaya Kusuma. 2003. Faktor-faktor yang Mempengaruhi Koefisien Respon Laba pada Perusahaan Bertumbuh dan Tidak Bertumbuh. Skripsi. Politeknik Universitas Brawijaya Malang.

Freeman, R. 1988. The Association Between Accounting Earnings and Security Returns. Journal of Accounting Research, 29, Spring.

Ghozali, Imam. 2005. Aplikasi Analisis Multivariat dengan Menggunakan Program SPSS. Universitas Gadjah Mada Press Yogyakarta. 2005.

Hartono, Jogiyanto. 2009. Teori Portofolio dan Analisis Investasi. BPFE UGM Yogyakarta.

Jang, Lesia, Bambang Sugiarto Dan Dergibson siagian. (2007). "Faktor Faktor Yang Mempengaruhi Kualitas Laba Pada Perusahaan Manufaktur Di BJ". Akuntabilitas. Vol 6 (2).

Jensen-Meckling (1976)"The Agency Theory Of The Firm : Managerial Behavior, Agency Cost And Ownership Structure" Journal of Financial Economics $3: 305-360$

Jogiyanto, Hartono, 2009, “Teori Portofolio \& Analisis Investasi, Yogyakarta : BPFE. Kartadjumena, E (2010), Pengaruh Voluntary Disclosure of Financial Information dan CSR Disclosure terhadap Earning Response Coefficient (Survey pada Perusahaan Manufaktur di BEI 2008-2009)", Jurnal Ekonomi Universitas 
Widyatama.

Kothari SP and RG Sloan, 1999 Information in prices about future earnings : Implications for earnings response coefficients. Journal of accounting and economics Kormendi R dan R. Lipe. 1987. Earnings Innovation, Earnings Persistence and Stock Return. Journal of Business

Lipe, RC, 1990, "The Relations Between Stock Return, Accounting Earnings and Alternative Information", Accounting Review (Januari).

Lev (1989). On usefulness of earnings : Lesson ans directions from two decades of empirical research. Journal of Accounting Research 27 (supplement

Lukman Syamsuddin. (2004). Manajemen Keuangan Perusahaan. Edisi Baru Cetakan 8. Jakarta: PT Raja Grafindo Persada

Naimah, Zahroh, dan Siddharta Utama, 2006, Pengaruh Ukuran Perusahaan, Pertumbuhan Laba,dan Profitabilitas Perusahaan terhadap Koefisien Respon Laba Dan Koefisien Respon Nilai Buku Ekuitas :Studi pada Perusahaan Manufaktur di Bursa efek Jakarta, "Simposium Nasional Akuntansi IX", Padang

Martini. 2007. Pengaruh Informasi Akuntansi Non Keuangan terhadap Earnings Response Coefficient. Skripsi. Riau University.

Mulyani, Sri et al. (2007). Faktor-Faktor yang Mempengaruhi Earnings Response Coefficient Pada Perusahaan yang Terdaftar di Bursa Efek Jakarta. Jurnal Akuntansi dan Auditing Indonesia (volume 11, no. 1).

Murwaningsari, Etty. (2008). Pengujian Simultan: Beberapa Faktor yang Mempengaruhi Earnings Response Coefficient $(E R C)$.

Penman, Stephen H. Financial Statement Analysis and Security Valuation. Singapore: Mcgraw Hill., 2001.

Palupi, Margaretta. (2006). “Analisis Faktor Faktor Yang Mempengaruhi Koefisien Respon Laba Bukti Empiris Pada Bursa Efek Jakarta”.Jurnal Ekubank, Vol 3. Melalui (Http://Akutansiku.Com).

Respiandi. 2012. Faktor-faktor yang Mempengaruhi Earnings Response Coefficient. Thesis. Universitas Bengkulu.

Rosianawati, Ana. A. Zubaidi Indra dan Agus Zuhron. 2011. Analisis Faktor-faktor yang Mempengaruhi Earnings Response Coefficient: Studi pada Perusahaan Property dan Real Estate yang Terdaftar di Bursa Efek Indonesia. Jurnal Akuntansi dan Keuangan Vol. 16 no. 1 Januari - Juni 2011. Universitas Lampung.

Silfi sulfiyah. (2010). Ukuran Perusahaan. (http://silfisulfiyah.blogspot.com/2010/12/ukuran-perusahaan.html) . 26 Oktober 2013

Scott, William R. (2009). Financial Accounting Theory 5th edition. Toronto: Prentice Hall.

Schwartz, K., dan Soo, B., 1996. "Evidence of Regulatory Non-Compliance with SEC Disclosure Rules on Auditor Changes". The Accounting Review 4th Ed. October.

Syafrudin, M. (2004). Pengaruh Ketidaktepatwaktuan Penyampaian Laporan Keuangan pada Earnings Response Coefficient: Studi di BEJ. Simposium Nasional Akuntansi, VII

Tiolemba, Noviyanti \& Ekawati, Erni. (2008). Analisis Faktor-Faktor yang Mempengaruhi Koefisien Respon Laba Pada Perusahaan Manufaktur yang Terdaftar di BEJ. Jurnal Riset Akuntansi dan Keuangan (volume 4, no. 2). 